The carrier-wave frequency is controlled to an accuracy of better than one part in a million by a high-precision quartz crystal, and the modulation arrangements of the transmitter have been designed to give a very high programme quality.

\section{Infestation of Grain by Insects}

A SURVEY of the conditions of infestation in the grain trade in Great Britain was initiated about a year ago (NATURE, June 4, 1938, p. 1004), as a result of which it appeared that research into control and remedial measures against pest infestation of all stored produce was desirable. At the request of a Standing Conference representing the industrial interests co-operating in the work, the Department of Scientific and Industrial Research has agreed to undertake this research and an advisory service for industry. The work will be carried out with the technical and financial co-operation of industry, by the Imperial College of Science and Technology at the Biological Field Station of the College, at Slough, under the direction of Prof. J. W. Munro, professor of zoology and applied entomology at the College, to whom inquiries relating to this new service should be sent. Industrial organizations interested in the work should communicate with W. McAuley Gracie, chairman of the Standing Conference on Pest Infestation, Department of Scientific and Industrial Research, 16 Old Queen Street, London, S.W.I.

\section{National Parks}

THE winter number of the Tree Lover (3, No. 26, De la More Press, $2 a$ Cork Street, London, W.1) includes an article on the case for national parks, which deals with the report of the Standing Committee on National Parks. In discussing this important question, many fall into the mistake of comparing Great Britain with Canada, the United States and other countries of the New and Old World of much larger size and with extensive tracts of wild, undeveloped countryside where great national parks or game reserves have been formed. These enthusiasts are apt to forget that Great Britain is, compared with such countries, a very small and densely populated island. This being said, the case for such national parks as are, or may be, feasible is a very strong one. As pointed out in the article in question, such a movement "falls in most signally with the aims of the Health Campaign on which the Government is at present engaged. If abundance of Playing Fields is essential for this, still more essential is the provision, or preservation, of national 'walking grounds', and regions where young and old alike can find refreshment and inspiration in the enjoyment of unspoilt Nature". The proposals of the Standing Committee on National Parks are well known. The chief question in connexion with these proposals is where the money is to come from. The suggestion is the Treasury. There is also a considerable body of influential opinion which considers that this question is one for the general public. That in fact if the public really want the national parks a fund should be opened to provide the money for their formation and upkeep; that the British public will attach a greater value to, and have a greater interest in, the maintenance of national parks provided by their own endeavour than if they are more or less controlled by the Government and therefore nobody's child.

\section{Meteorology for Airmen in India}

A PAMPHLET of the India Meteorological Department, having the title "Meteorological Organisation for Airmen", brings up to date the information required by airmen in India who wish to take advantage of available information about actual and expected weather on the various aviation routes in that country. There are several classes of meteorological station in the organization that is concerned with meeting the demands of aviation, of which the most important are the forecasting centres where synoptic weather charts are prepared twice a day, namely, for civil aviation (Karachi, Calcutta and Poona), and for military aviation (Karachi and Peshawar). The India Meteorological Department is responsible for the aviation weather service on the trans-India route from the Gulf of Oman to Akyab, as well as along other internal air routes in India. The positions of the four types of meteorological station more directly concerned with the supply of information-the eivil and military forecasting eentres, the pilot balloon stations where the winds aloft are measured, and the aeronautical wireless stations-are clearly shown on a folding map. The codes for transmitting information about the weather have become more numerous in the course of years, in proportion as the information required has become more detailed and precise, and practically the whole of this pamphlet is taken up with them. Attention is directed in a foreword to a change instituted on July 1, 1937, which resulted from the establishment of an independent meteorological service in Burma. From that date the Calcutta Meteorological Office ceased to issue weather reports and forecasts for air routes in Burma and the 'general inference' for the Rangoon-Bangkok section, these being taken over by the Meteorological Office at Rangoon, but it has continued to issue reports and forecasts for the Calcutta-Akyab route.

\section{"Earning whilst Learning" in American Universities}

THE economic depression in the United States compelled university administrators and students to devise fresh plans for enabling poor undergraduates to pay their way. The Federal Government decided to help, not with scholarship grants but by financing work projects through the National Youth Administration. So new ways were discovered for using student labour and some proved so beneficial to all concerned that they became permanent. A summary of the more important is given in Bulletin No. 9 of the Office of Education (Supt. of Documents, Wash. ington, D.C. 10 cents). This gives particulars of factories, printing-presses and other money-earning projects, of co-operative housing and other schemes for reducing students' living costs, and of the 'selfhelp' colleges which aim at making education as 